\title{
Response to Druwe and Burgoon, 2016 Letter to the Editor in Archives of Toxicology
}

\author{
Samuel M. Cohen ${ }^{1} \cdot J^{\prime}$ I. Goodman ${ }^{2} \cdot$ James E. Klaunig $^{3} \cdot$ Lora L. Arnold $^{1}$
}

Received: 19 October 2016 / Accepted: 2 November 2016 / Published online: 9 November 2016

(C) Springer-Verlag Berlin Heidelberg 2016

We thank Drs. Druwe and Burgoon for their clarification of the Bayesian analysis (Druwe and Burgoon 2016) of the data from the studies by Waalkes and his colleagues (Tokar et al. 2011; Waalkes et al. 2014). The critical issue being raised by us, however, is not the statistics but rather the biology. Spontaneous lung tumors in this strain of mice are extremely common, with reports in the literature ranging from a low of 8.8 to a high of $61.1 \%$ with an average of $21.8 \%$ (Manenti et al. 2003). This appears to be related to a susceptibility gene for lung tumors present in many strains of mice including CD-1 (Manenti et al. 2003). Dr. Waalkes' laboratory has reported incidences of lung tumors in control mice from their studies ranging from 20 to $42 \%$ [20\% (Tokar et al. 2012b), 22\% (Waalkes et al. 2014), 34\% (Tokar et al. 2011), and 42\% (Tokar et al. 2012a)]. This variability could be due to a variety of factors including normal variation in incidences as well as differences in diet, water, handling procedures, and others. For example, note that the Waalkes group used a Ralston Purina noncertified rodent diet, 5L79 which has not been analyzed for contaminants (personal communication with Dr. Melanie Hoar, PMI Nutrition International Technical Services) and the sources of its component parts vary over time depending on availability. One of its components, fish meal (Purina diet composition sheet for 5L79), is rich in arsenic. The Waalkes group did not measure arsenic in their diets (Waalkes et al. 2014). They did reference arsenic levels in a

Samuel M. Cohen

scohen@unmc.edu

University of Nebraska Medical Center, Omaha, NE, USA

2 Michigan State University, East Lansing, MI, USA

3 Indiana University, Bloomington, IN, USA
Purina certified diet with similar components but that does not ensure that those are the same arsenic levels in the diets used in the reported study.

The tumor incidences in their treated groups at low doses are within the range stated above for their control groups and are not statistically significant at $p<0.01$. Unfortunately, Druwe and Burgoon dismissed the use of $p<0.01$ without providing a rationale for their action. The basis for this statistical analysis was provided by Haesman (1983, 1984) and Haseman et al. $(1984,1986)$ who was the chief statistician for the National Toxicology Program bioassay program. He suggested using $p<0.01$ for common tumors for the very reason that is evident in the studies by Waalkes and his colleagues, that is, there is wide variability from group to group, making chance variation much more likely. The use of $p<0.01$ when dealing with common tumors has been accepted for regulatory purposes by the United States Food and Drug Administration Carcinogenicity Assessment Committee (CAC), in addition to other regulatory agencies around the world. To interpret the results of Waalkes and his colleagues any other way than by chance is to raise serious questions about a very peculiar dose response. To suggest that the higher doses produced a lower incidence of tumors because of toxicity is not consistent with the actual findings, since at even higher doses they had increased incidences of tumors. Furthermore, at all of these doses, there is no evidence of pulmonary toxicity in these mice. In addition, others have not been able to reproduce the lung tumors findings of any of Waalkes' studies (Garry et al. 2015; Ahlborn et al. 2009; Nohara et al. 2012; Takumi et al. 2015).

Although Druwe and Burgoon might have performed an acceptable Bayesian analysis, it is not biologically relevant to interpretation of the findings. This is the key point. Taking into account statistical analyses and biology, one can only conclude that there is no effect of inorganic arsenic on 
the incidence of lung tumors in mice at all three low doses reported by Waalkes and his colleagues.

\section{References}

Ahlborn GJ, Nelson GM, Grindstaff RD, Waalkes MP, Diwan BA, Allen JW, Kitchin KT, Preston RJ, Hernandez-Zavala A, Adair B, Thomas DJ, Delker DA (2009) Impact of life stage and duration of exposure on arsenic-induced proliferative lesions and neoplasia in $\mathrm{C} 3 \mathrm{H}$ mice. Toxicology 262:106-113

Druwe IL, Burgoon L (2016) Revisiting Cohen et al. 2015, Cohen et al. 2014 and Walkes et al 2014: a Bayesian re-analysis of tumor incidences. Arch Toxicol 90:2047-2048

Garry MR, Santamaria AB, Williams AL, DeSesso JM (2015) In utero arsenic exposure in mice and early life susceptibility to cancer. Regul Toxicol Pharmacol 73:378-390

Haseman JK (1983) A reexamination of false-positive rates for carcinogenesis studies. Fundam Appl Toxicol 3:334-339

Haseman JK (1984) Statistical issues in the design, analysis and interpretation of animal carcinogenicity studies. Environ Health Perspect 58:385-392

Haseman JK, Huff J, Boorman GA (1984) Use of historical control data in carcinogenicity studies in rodents. Toxicol Pathol 12:126-135

Haseman JK, Winbush JS, O'Donnell MW Jr (1986) Use of dual control groups to estimate false positive rates in laboratory animal carcinogenicity studies. Fundam Appl Toxicol 7:573-584
Manenti G, Galbiati F, Noci S, Dragani TA (2003) Outbred CD-1 mice carry the susceptibility allele at the pulmonary adenoma susceptibility 1 (Pas1) locus. Carcinogenesis 24:1143-1148

Nohara K, Tateishi Y, Suzuki T, Okamura K, Murai H, Takumi S, Maekawa F, Nishimura N, Kobori M, Ito T (2012) Late-onset increases in oxidative stress and other tumorigenic activities and tumors with a Ha-ras mutation in the liver of adult male $\mathrm{C} 3 \mathrm{H}$ mice gestationally exposed to arsenic. Toxicol Sci 129:293-304

Takumi S, Okamura K, Suzuki CT, Hano H, Nohara K, Yanagisawa $\mathrm{H}$ (2015) Gestational arsenic exposure affects gene expression in the kidney and lung in F1 and F2 mice. In: 54 th annual meeting and ToxExpo. The toxicologist supplement to toxicological sciences, San Diego, California, USA, March 22 -26 2015, p 422

Tokar EJ, Diwan BA, Ward JM, Delker DA, Waalkes MP (2011) Carcinogenic effects of "whole-life" exposure to inorganic arsenic in CD1 mice. Toxicol Sci 119:73-83

Tokar EJ, Diwan BA, Thomas DJ, Waalkes MP (2012a) Tumors and proliferative lesions in adult offspring after maternal exposure to methylarsonous acid during gestation in CD1 mice. Arch Toxicol 86:975-982

Tokar EJ, Diwan BA, Waalkes MP (2012b) Renal, hepatic, pulmonary and adrenal tumors induced by prenatal inorganic arsenic followed by dimethylarsinic acid in adulthood in CD1 mice. Toxicol Lett 209:179-185

Waalkes MP, Qu W, Tokar EJ, Kissling GE, Dixon D (2014) Lung tumors in mice induced by "whole-life" inorganic arsenic exposure. Arch Toxicol 88:1619-1629 